\title{
PREPARING AND PRESENTING A CONSERVATION BOARD HEARING IN SASKATCHEWAN*
}

\begin{abstract}
This article examines the practice and procedure of the Saskatchewan Oil and Gas Conservation Board on an application for a statutory unitization order, with particular reference to the application, the hearing and the order. The article compares the advantages and disadvantages of statutory unitization with voluntary unitization and concludes by making several recommendations to correct difficulties and problems in the present practice and procedure of the Saskatchewan Oil and Gas Conservation Board.
\end{abstract}

\section{A. A BRIEF HISTORY OF CONSERVATION LEGISLATION AND PRACTICE IN SASKATCHEWAN}

A comparison of The Oil and Gas Conservation Act of Saskatchewan ${ }^{1}$ and the "Model Conservation Statute" of the Interstate Oil Compact Commission" reveals a number of similarities in the approach taken in the two statutes. The history of the Saskatchewan statute illustrates how this came about.

In 1948 and 1949 the great exploration plays which led to the discovery of oil in southwest and southeast Saskatchewan began to take shape. Prior to that time, exploration for petroleum in the province had been on a limited scale, and by 1948 the only production in the province was a relatively small amount of heavy oil and some gas in the Lloydminster area.

By 1951 the exploration programs which led to the discovery of oil in the Fosterton area were underway, and by this time the need for a conservation statute had become obvious. Meetings between industry and government for the purpose of considering this subject took place in December of 1951.

The need for advice from persons experienced in the field of oil and gas conservation was obvious during these early deliberations, and shortly after the first meetings, the Saskatchewan Department of Mineral Resources sought advice from the office of the Interstate Oil Compact Commission in Oklahoma City. The Interstate Compact is a compact of oil producing states dedicated to proper conservation practice in the production of oil and gas." Many of the members of its staff are experts in fields of conservation practice and legislation.

As the name would imply, the activities of the Interstate Oil Compact Commission are generally confined to the oil producing areas in the United States of America. Notwithstanding this, the office of the Interstate Oil Compact Commission responded generously to the Saskatchewan government's request for advice, and a number of its representatives with wide experience in oil and gas conservation matters contributed a great deal of time and thought in the consideration of the Saskatchewan situation. Under these circumstances it is not surprising that a number

- This paper was prepared through the combined efforts of B. V. REED and JOHN STE'N, both of MacPherson. Leslie and Tyerman, Regina: E. J. MOSS and R. J. BALFOUU, both of Balfour. MacLeod, McDonald, Moss, Laschuk and Kyle, Regina; W. G. LOEWEN, of Francana Oll and Gas Ltd., Regina; and W. F. READY, of McDougall, Ready, Wakeling, Youck and Mollard, Regina.

1 R.S.S. 1965, c. 360 .

2 Interstate Oil Compact Commission, $A$ Form for an Oil and Gas Conservation Statute.

3 The text of the Interstate Compact to Conserve Oil and Gas is set out in Interstate Oil Compact Commission. A Study of Conservation of Oil and Gas, 9-10 (1964). 
of the principles and approaches which are embodied in the Interstate Compact model statute found their way into the Saskatchewan Oil and Gas Conservation Act.

In terms of theory at least, there is much of the ideal in the model statute of the Interstate Compact. In spite of the reason and logic on which it is based, however, at the time that it was being considered as a basis for a Saskatchewan act, the model statute was nowhere in effect in any of the member jurisdictions of the Interstate Oil Compact Commission. The reason for this is not difficult to find. In terms of oil and gas production, the member states are older jurisdictions, and by the time the model statute came into existence they were under the influence, often deep-rooted, of royalty owners organizations and other pressure groups who favor the immediate returns of uncurtailed production over the long-run benefits of proper conservation practices. In Saskatchewan, which was then a relatively new producing jurisdiction, there was a great opportunity to embody in the proposed conservation statute many of the principles to which the members of the Interstate Compact dedicate themselves in the conservation of oil and gas. ${ }^{4}$

In result, the model statute of the Interstate Compact was used as a basis for Saskatchewan Conservation legislation. It had, of course, to be recast into Saskatchewan legislative form, and matters of practice in dealing with conservation problems had to be worked out on a basis acceptable under Saskatchewan administrative procedures. By early 1952 all of this had been worked out, and the first statute and regulations appeared in March of that year."

Even if their details were available, nothing would be gained by reviewing all of the items which industry and government dealt with in framing the Saskatchewan Oil and Gas Conservation Act. There are two issues, however, which should be mentioned. The first is the question of compulsory unitization, and the second relates to the constitution of the oil and gas conservation board.

During the discussions, industry was opposed to compulsory unitization except on the basis of a plan concurred in by the representatives of a specified percentage of the working interest. The government took the position that in the interests of good conservation practice power to compel unitization might well be necessary, and in the final result the statute was set up on this basis. By virtue of a 1966 amendment $^{\circ}$ unitization can now be achieved by agreement, and where this is done, all that the board requires is the filing of the agreement and any amendments thereto.

On the second question, industry favored a more or less independent board similar in constitution to that which was then in existence in Alberta with government and industry sharing the cost. The government concluded that the interests of all concerned would best be served by a board responsible to the Minister, and accordingly the Chairman of the Board has always been the Deputy Minister of Mineral Resources.

The first board was established under the chairmanship of $\mathrm{Mr}$. C. A. L. Hogg who was'then the Deputy Minister of Mineral Resources. The other two members were the late Prof. F. H. Edmunds, of the

4 See Article III of the Compact. id., at 9.

s. S.S. 1952, c. 88.

6 S.S. 1966, c. 66 . 
Department of Geology of the University of Saskatchewan and later Dean of the Faculty, and Dr. J. W. T. Spinks then of the Department of Chemistry and now President of the University of Saskatchewan. Other appointments have been made from time to time. All appointments are made by the government, but it must be said that this is always done in consultation with industry.

Even a brief reference such as this to the history of oil and gas conservation in Saskatchewan would be incomplete without mention of the late Dr. H. H. Kaveler of Oklahoma City. Naturally, the first oil and gas conservation board was lacking in experience in conservation matters, and because of this the Saskatchewan government retained Dr. Kaveler as a consultant to the board. Dr. Kaveler or "Herman" as he was known to all those who appeared before the board was a graduate of the Missouri School of Mines with wide experience in oil and gas conservation. Dr. Kaveler remained as advisor to the board until his death on June 3, 1966.

\section{B. PRACTICE AND PROCEDURE FOR BOARD HEARING}

The Oil and Gas Conservation Act of Saskatchewan' makes provision for two types of oil and gas units, a "statutory unit"s and a "voluntary unit".

The statutary unit is brought into existence by order of the Lieutenant Governor in Council made pursuant to the provisions of Section 35 (1) of the Act which provides as follows:

Upon the recommendation of the minister after the hearing, the Lieutenant

Governor in Council may order that the field or pool or portion thereof be operated as a unit.

The voluntary unit is brought into being by an agreement of the "owners and any other person having a proprietary interest in the oil or gas in a field or pool or any portion of such field or pool."10 Section $43 a$ (3) provides that an executed copy of the agreement for voluntary operation shall be filed with the minister prior to the effective date of the unit operation and that thereafter all amendments to such an agreement shall also be filed with the minister.

The first statutory unit, the Brock Viking Sand Unit, was formed pursuant to the order of the Lieutenant Governor in Council made in March of 1954. Since that time a total of 61 statutory units have been formed in Saskatchewan, 3 of which are gas units and 58 are oil units. As of the 1st of May, 1968, all of these units were still in operation with the exception of one which was in the process of being abandoned because the wells were no longer capable of economic production.

Section 43a, which provides for voluntary units, was not added to the Act until the 7th day of April, 1966, ${ }^{1}$ and the first voluntary unit agreement was filed with the minister pursuant to that Section on the 30th day of August, 1966, and related to the Ingoldsby Mission Canyon Voluntary Unit with Imperial Oil Limited as operator. Up to the 1st day of May, 1968, a total of 15 voluntary unit agreements had been filed with the minister, 12 of the agreements covered oil units and the other 3 covered gas units.

\footnotetext{
R.S.S. 1965 , c. 360 .

ss. $34-43$.

o s. $43 \mathrm{a}$.

10 s. $43 a$ (1)

11 S.S. 1966 , c. 66
} 


\section{STATUTORY UNITS}

\section{(i) The Application}

Section 34(1) of the Act provides that the minister may on his own motion and upon application of any interested person shall order that a hearing be held by the Board to consider the need for the operation as a unit of an entire field or pool. The application for a unit order must be in writing and must be accompanied with supporting material. Under the current practice the applicant is required to provide the minister with the following:

(a) 10 copies of the application,

(b) 10 copies of the proposed plan of unit operations,

(c) 10 copies of the supporting material."'

The application is usually in the form of a letter to the minister in which the formal request for a unit order is made and the proposed unit operations are briefly outlined.

There is no statutory form of unit plan provided for in the Act, however, the Department maintains a model plan and Department officials generally recommend that that model plan be followed. ${ }^{13}$ The model plan of the Department is usually contained in the most recent unit order and as a matter of practice, Department officials will normally refer a proposed applicant to the most recent order for a precedent as to the plan of unit operations.

The supporting material is prepared by the applicant or perhaps more accurately by a committee composed of representatives of interested parties and consists of technical material respecting the reservoir in question, the proposed method of unit operations, estimates of future production and the proposed distribution of that production among the owners of the various tracts involved. The type of and extent of the material and information which ought to be filed in support of an application will vary from application to application but generally the material will include an engineering and geological study and an economic feasibility study respecting the proposed unit operations. The material must also include information as to how the suggested tract factors were arrived at and what parameters were used.

While there is no express provision in the Act which enables the minister to refuse to order a hearing where he has received an application from an interested person or persons, in practice the officials of the Department of Mineral Resources check the material filed in support of an application prior to setting a date for a Board hearing and if in the opinion of the officials of the Department, the material should be more complete or should be clarified, they will communicate with the applicant in an effort to clarify and amplify the material which has been filed. This process goes on between the time that the material is filed and the hearing date set and thus far this practice appears to have been quite beneficial to all interested parties.

\section{(ii) The Hearing}

The application goes to the Oil and Gas Conservation Board which presently consists of four members, one of whom is the Chairman. A quorum of the Board consists of two members.

1: Oil and Gas Conservation Regulations, O.C. 2272/68, s. 105 (1).

13 See Model Oil and Gas Unit Agreement approved by the Petroleum and Natural Gas Committee at the 25 th Mines Ministers Conference, September, 1968. 
The Board does not have regular sittings. The date for the hearing is proclaimed by the Board in the notice of the hearing. This is not to say that the date is arbitrarily selected but rather on the contrary there are usually discussions between the applicant and officials of the Department as to what would be the most convenient and suitable date for the hearing of the application and every effort is made to select a date which is mutually satisfactory. Once the date is selected and the notice of hearing gazetted the Board is reluctant to change the date; however, it will for a good reason grant an adjournment or a number of adjournments.

Section 47 of the Act provides that notice of the hearing shall be given to the applicant by registered mail and published in one issue of the Gazette and in one issue of a newspaper having general circulation in the district in which the field or pool in question is situated at least 10 days prior to the date set for the hearing. Where preliminary indications are that all of the affected parties have agreed to the proposed plan of unit operations and there will be little or no opposition to the application, the minimum amount of notice is often given; however, where it appears that the application will be contested, substantially more than the minimum 10 days notice of the hearing is given.

The notice itself is prepared by Government officials who are responsible also to see that the notice is properly gazetted and published in a newspaper in compliance with Section 47 of the Act.

It would perhaps be in order to make a brief comment on the preparation of what has been termed the "technical material" which is filed in support of an application. That material, consisting of engineering studies, geological reports, feasibility studies and so on, is invariably prepared by or under the direction of a technical committee composed of representatives of the various oil companies who have interests in the area of proposed unit operations. Under the practice to date, the lawyer is actually not involved in the preparation of the technical material nor in the decision as to what evidence and material ought to be prepared in support of the application. While it is true that normally the lawyer is not competent to advise as to the technical side of the application, he is in no different position with respect to a unit application than he is with respect to a lawsuit, and it is suggested that the lawyer is quite competent to advise as to what will have to be proved and to comment on the type of material that ought to be prepared and the type of studies that ought to be made, and generally the type of material and evidence that should be tendered in support of the application. This would appear to be particularly so in the case of contentious applications. It is submitted that it is advisable to bring the lawyer into the picture at the earliest possible date and that this will have beneficial results.

\section{(iii) Practice and Procedure}

Part VI of the Act deals with the practice and procedure relating to hearings. Section 44 provides that the Lieutenant Governor in Council may prescribe rules and regulations governing the practice and procedure with respect to hearings. To date the only rules and regulations which have been passed pursuant to Section 44 are contained in Section 105 of the Oil and Gas Conservation Regulations. ${ }^{14}$

\footnotetext{
14 Supra, n. 12.
} 
Evidence before the Board is given under oath ${ }^{15}$ and Section 50 (2) of the Act provides that the Board has the powers conferred or that may be conferred upon commissioners under The Public Inquiries Act. ${ }^{16}$ Hearings of the Board are open to the public and all interested parties may be heard. ${ }^{17}$

The normal practice has been for the applicant to be represented by a lawyer (either a house counsel or an outside counsel) who leads the evidence and conducts the cross-examination on behalf of the applicant. Persons who object to the application or to certain aspects of it are also normally represented by counsel. There have been cases, however, usually uncomplicated and non-contentious applications, where the application has been presented by someone other than a lawyer, usually an engineer or geologist.

Unlike the case in other jurisdictions, in Saskatchewan royalty owners rarely attend unit application hearings either personally or through counsel, and in Saskatchewan the practice appears to have developed for the Board to endeavour to exercise a sort of "guardian angel" role with respect to royalty owners and to endeavour to see that they are treated equitably. The lack of complaints from royalty owners would tend to indicate that the Board is discharging this function rather well, however, one could speculate that the lack of objections may be due as much to the fact that the royalty owners are not aware of the extent to which they have been affected or may be affected by a unit order and, accordingly, have not been able to come to any judgment on the matter.

In Saskatchewan the Provincial Crown is a large mineral and royalty owner and almost always has some interest in any proposed unit. Its position is asserted and protected by Department officials.

\section{(iv) The Order}

The Board does not make the unit order; rather, it may recommend to the minister that a particular field or pool or portion thereof be operated as a unit or it may recommend against unit operations for the said field, pool or portion thereof. ${ }^{1 s}$ The Act specifies that upon the recommendation of the minister, the Lieutenant Governor in Council may order that a particular field, pool or portion thereof be operated as a unit. ${ }^{19}$

The minister is not obligated to follow the recommendation of the Board, nor is the Lieutenant Governor in Council obligated to follow the recommendation of the minister, however, while the only decision or recommendation that is made public is the recommendation of the Lieutenant Governor in Council, one is inclined to conclude from available evidence that the minister normally follows the recommendation of the Board and the Lieutenant Governor in Council normally follows the recommendation of the minister.

In order to recommend unit operations for a particular field, pool or portion thereof the Board must find that:

(a) the operation of a field or pool or a portion thereof as a unit is reasonably necessary to prevent waste, to increase substantially the recovery of oil or gas and to protect correlative rights; or

15 Oil and Gas Conservation Act, R.S.S. 1965, c. 360 , c. $105(8)$.

16 R.S.S. 1965, c. 19.

$1 i$ s. $45(2)$.

18 s. $34(4)$.

19 s. $35(1)$. 
(b) the value of the estimated additional recovery of oil or gas resulting from the operation of a field or pool or a portion thereof as a unit will exceed the estimated additional cost, if any, incidental to the conduct of the operation; or

(c) the operation of a field or pool or a portion thereof as a unit will result in general advantage to the owners of the oil and gas rights within the field or pool or portion thereof; [Emphasis added]²

Prior to 1964, before the Board could recommend unitization to the minister, it had to find that all three of the above stated objectives of unitization were present, because the section then contained the word "and" in place of the above italicized word "or.""1

\section{(v) Appeal}

There is no provision in the Act for an appeal from either the Lieutenant Governor in Council's decision to order a unit or to refuse to order a unit. ${ }^{22}$ This point is dealt with more extensively in Part $\mathrm{C}$ of this paper.

\section{VOLUNTARY UNITS}

In 1966 the Act was amended by the addition of Section 43a which provides for voluntary unitization. Section $43 a$ states:

(1) Notwithstanding anything in this Part, the owners and any other person having a proprietary interest in the oil or gas in a field or pool or any portion of such field or pool may enter into an agreement for the operation of such field or pool or portion thereof as a unit.

(2) A unit operation agreement entered into under subsection (1) shall set forth a scheme or plan for combining the interests of the owners and other persons having a proprietary interest in the common source of supply of oil or gas in the field or pool or portion thereof.

(3) An executed copy of an agreement for unit operation entered into under subsection (1) shall be filed with the minister prior to the effective date of the unit operation. All amendments to such an agreement shall also be filed with the minister."

There was nothing in the Act prior to the addition of the said Section to prevent persons from agreeing to the operation of a field, pool, or portion thereof as a unit and, provided the other provisions of the Oil and Gas Conservation Act and Regulations were complied with, ${ }^{23}$ unit operations could be carried out without a Board order.

It is submitted that Section 43a does not effect a substantial change. Subsection (3) provides that an executed copy of the agreement must be filed with the minister prior to the effective date of unit operations and that thereafter, all amendments to the agreement must also be filed with the minister, however, there is nothing in the section itself or elsewhere in the Act which gives such a voluntary unit agreement, when filed, the same status as a unit formed pursuant to an order of the Lieutenant Governor in Council under Section 35 of the Act. It is submitted that a unit formed under Section 43a of the Act depends entirely for its force and effect upon the unit agreement and that the rights and obligations of the parties to such an agreement are entirely contractual and are to be found within the four corners of the agreement.

Sections 36 to 39 and Sections 41 and 42 deal with the rights and duties of an operator under a unit agreement, operations under a unit agreement and the effect of unit operations after an order has been made under Section 35. These provisions and the unit order, insofar as they are

21 S. 34 (4). 1964 , c. 26.

21 S.S. 1964,

23 E.g. $s$. 51 , which requires approval of the minister for any repressuring, cycling or maintenance plan. 
relevant and applicable, are binding upon all persons including the Crown and draw their force and effect not from an agreement among those persons but rather from the statute.

Obviously great care has to be taken when a voluntary unit is formed under Section 43a of the Act. All persons whose rights or interests are affected should be parties to the agreement and the agreement itself should clearly specify what other agreements (i.e. leases, farmouts, etc.) are being varied and the exact extent of the variation. All persons who are affected have to specifically agree that the portion of unit production allocated to a separately owned tract under a voluntary unitization agreement shall for all purposes be deemed to have been actually produced from the tract and that the unit operations shall be deemed to be in fulfillment of all express and implied obligations of the owner of the tract or the producer under all leases and contracts applicable thereto. Indeed, one might consider incorporating Section 42 of the Act in the voluntary unit agreement.

As has been herein noted, ${ }^{,-1}$ since Section $43 a$ was added to the Act, a total of 15 voluntary unit agreements have been filed with the minister, and it would appear that voluntary unit agreements are quite popular at the moment with producers. It is respectfully submitted, however, that unit operations pursuant to a voluntary unit agreement are fraught with danger and accordingly must be most carefully drafted.

It is obvious that before operations can be carried out under a voluntary unit agreement formed under Section 43a of the Act, the parties will have to come to an agreement, and if the parties are in agreement, then it is suggested that it would be advisable to take the extra time and effort to obtain an order under the Act, assuming that the difficulties therein, as raised in part $C$ of this paper are sorted out, so that the operations can be afforded the protection of operations carried out under a statutory unitization that results from an order under Section 35 of the Act.

\section{DIFFICULTIES, PROBLEMS, RECOMMENDATIONS}

There have been a considerable number of oil and gas units established under the Oil and Gas Conservation Act in Saskatchewan, and in view of the great value of the assets thus unitized and the complexity of the unit plans, it is remarkable that one can say that, in general, units have been established and operated with great co-operation among all those concerned and with generally happy results. This state of affairs reflects great credit on the Oil and Gas Conservation Board, the Saskatchewan Department of Mineral Resources and the members of the oil and gas industry. The changes in the pre-existing order caused by the establishment of the unit plan are, however, so great and so complex that it is inevitable that from time to time the parties affected are dissatisfied and serious individual problems arise.

Since the intent of the Act and the general intention of all parties is to unitize on an equitable basis, and since the result of a unit is generally to increase the overall production or to reduce the overall cost of production, the financial consequences to each working interest owner on the establishment of the unit are generally favourable and problems

\footnotetext{
24 Supra, n. 11.
} 
have not arisen. In the unusual case, however, of the income of the working interest owner dropping after unitization, it is easily understandable how a feeling of grievance can arise.

Such a grievance is less likely to arise in the case of a voluntary unit, since owners are unlikely to participate in a voluntary unit agreement unless they are satisfied with the terms thereof. If, however, a problem arises in respect of a compulsory unit, the dissatisfied owner is likely to feel extremely ill-used and will not easily find any remedy. There seems to be no effective appeal.

It is therefore incumbent upon parties affected by proposed compulsory unitization to do their utmost to obtain full information in connection with the proposals and if dissatisfied therewith to make the best possible case in objection at the hearing before the Oil and Gas Conservation Board.

Although the possibility of an unfair tract factor being allocated under the present system may be unlikely, it must be admitted that an inequitable tract factor is tantamount to expropriation of property without adequate compensation. It is believed that in all cases of expropriation in Saskatchewan in respect of property of the value of $\$ 500$ or more, a right of appeal exists, and that the absence of an appeal in the case of oil and gas utilization may be an unjustifiable exception to the general rule. ${ }^{2 \pi}$

Section 40 of the Oil and Gas Conservation Act makes it possible for a unit operation order to provide for a rehearing by the Oil and Gas Conservation Board. The text of the section is as follows:

(1) An order under section 35 may provide for a rehearing by the board upon the application of any interested party on or after a future date specified in the order.

(2) Upon the recommendation of the minister following such rehearing, the Lieutenant Governor in Council may amend or revise a unit operation order in order to supply any deficiency therein or to meet changing conditions, and may alter or revoke any provision therein that is deemed to be unfair or inequitable and may add to the unit area therein described any area that the minister believes to be underlaid by the pool or one of the pools underlying the unit area.

Pursuant to this section, the unit operation order generally includes a clause as follows:

Any interested person may at any time after the effective date, apply to the Minster for a rehearing by the Board in respect of this plan.

It will be seen that this provision for a rehearing does not go very far. A party requiring such a rehearing only appears to have the right to apply for it and cannot apparently compel a rehearing, nor is it likely that a rehearing by the Oil and Gas Conservation Board, will, in the absence of any change in circumstances, result in any change in the plan. It is therefore submitted that Section 40 and the consequent right to apply for a rehearing cannot in any sense of the word be regarded as a method of appeal. Once the unit operation order has been promulgated, it would seem that the person affected thereby has no alternative but to submit to the effect of unitization, however harsh the result may appear. If he can show that the unit plan has not been brought into operation strictly in accordance with the provisions of the Oil and Gas Conservation Act,

2.: See Expropriation Act, R.S.S. 1965, c. 56; Expropriation Procedure Act, S.S. 1968, c. 21; Surface Rights Acquisition and Compensation Act, S.S. 1968, c. 73. 
he may be able to set it aside in the Courts. If he can obtain a rehearing and then perform the unlikely feat of persuading the Oil and Gas Conservation Board to decide that it was previously mistaken, change its mind and recommend to the Minister to recommend in turn to the Lieutenant Governor in Council that the unit plan should be changed, he may remedy the position. Failing either of those two alternatives, the party is compelled to submit to the unitization, as ordered.

Until recently an unincorporated association of more than twenty persons to carry on business for the purpose of gain was prohibited by Section 4 of the Companies Act." ${ }^{13}$ This raised some concern as to the power of more than twenty persons to form a voluntary unit, but the problem has been remedied by an amendment to the Companies Act passed at the 1968 session of the legislature ${ }^{27}$ relating to aggregations of persons forming property management groups, as in the case of oil and gas unit operations.

Serious objections on compulsory unitization hearings appear to arise with less frequency than they did in the earlier days of compulsory unitization, because, in general, all parties concerned are in co-operation in the preparation of the plan and most problems are settled and smoothed away before the matter gets to the hearing stage. Problems can arise on the hearing, however, in the presentation of the objector's case for the following reasons:

1. The applicant's case for unitization is normally prepared in great detail over a considerable length of time and an objector who, whether it be his own fault or not, has not been fully acquainted with all the details of preparation and with the activities of the steering committee may find himself rather short of time to make an adequate presentation in objection, if he first hears of the matter when the Oil and Gas Conservation Board gives notice of the hearing.

2. If the objector is only concerned with a small area of the unit, it is well nigh impossible for him, if of limited means and resources, to make an adequate presentation and objection. If he criticizes the particular tract factor of his well, he cannot make an effective argument to support a different tract factor unless he not only reviews the performance and qualities of his own well, but the performance and qualities of all the other wells of the unit. This is generally an impossible task to attempt within the time and means available.

It would appear that unitization is desirable, and it would seem to be very unlikely that when unitization is requested and supported by a majority of the owners concerned, unitization would not result on some terms. There is, accordingly, sometimes a danger that the applicant's unit plan, although open to some justifiable criticism, is accepted because it is the only comprehensive plan available.

3. It seems probable that the Oil and Gas Conservation Board does not form its views and make its recommendations solely on the evidence put before it at the hearing but that it has recourse to opinions, studies and the results of work performed by the technical staff of the Department of Mineral Resources and also the views and experience of its own members in their respective fields of expertise. There may be good reasons for this and it is not suggested that this attitude 
by the Board and the results often achieved thereby are unjustified. However, on occasion it causes concern to the parties appearing before the Board who would probably prefer to know all the views and evidence on which the Board bases its recommendations so that if disagreement was felt with any of those views, further evidence could be brought before the Board in an attempt to rebut them.

4. It is sometimes difficult for a person with a small royalty interest to be sufficiently informed and to have sufficient resources to appear before a unitization hearing or to make a proper presentation.

The above objections must not obscure the fact that in general the results of unitization have been beneficial.

The fact that there has been no legal decision in the Courts, to the writer's knowledge, as to the validity of a compulsory oil and gas unit, is, after a considerable number of years of compulsory unitization, a creditable achievement to all concerned, but there are undoubtedly interesting legal problems capable of arising. Answers to some of these problems may be given in a lawsuit presently pending in the Court by which the plaintiff, a working interest owner, seeks to obtain a declaration that a compulsory unit under the Oil and Gas Conservation Act is irregularly constituted and therefore invalid. No attempt will be made in this paper to go into the details of that action, nor to attempt to argue that case, but the nature of the problem arising can be indicated in general as is done hereunder:

1. Section $35(2)$ of the Oil and Gas Conservation Act specifies certain things that a unit order "shall include". Among these items is specified in clause (c) "an allocation among the separately owned tracts in the unit area of all the oil and gas produced and not required in the conduct of such operation or unavoidably lost, such allocation to be based proportionately on the contribution, other than physical equipment, made by the owners of the separately owned tracts to the unit operation." This appears in rather complicated language to indicate that each tract should have a "fair share". The question therefore arises whether it must be assumed that the allocation of tract factors by the Lieutenant Governor in Council among the various tracts is a fair share, or whether it is open to an owner to establish in the Courts that he has not received a fair share and, in consequence, to argue that the unit plan is not in accordance with Section 35, and therefore invalid.

2. As a preliminary to unitization, Section $34(1)$ provides that the Minister may order a hearing to be held by the Oil and Gas Conservation Board to consider the need for the operation as a unit "of an entire field or pool". The question therefore arises as to whether the unitization can be challenged by showing that the area which the Board had been ordered to consider is not an entire field or pool, but only a part thereof.

3. The possibility arises that a unitization order under the Oil and Gas Conservation Act may affect banking transactions under Section 82 of the Bank Act with the possible consequence that the provincial unit may conflict with the Bank Act, and in consequence be invalidated. 
In order to avoid the difficulties above mentioned, it seems that where possible, it is preferable to establish a voluntary unit rather than a compulsory one, and it is perhaps significant that since 1966 when a voluntary unit first became possible in Saskatchewan by the enactment of Section 43a of the Act, this method has become widely used.

A note of caution should be expressed here as to the advisability of ensuring that all parties entering into such a voluntary agreement do so with the full appreciation of the effect of it. There is normally no difficulty whatever in connection with oil companies in this regard, since they are familiar in these matters and not likely to execute such agreements without a full realization of the consequences. It is understood that there have been complaints by royalty owners who, having executed voluntary agreements, later become dissatisfied with the effect of the unitization upon their royalty interest. However, the possibility of problems arising should be much less in the voluntary field than in the case of compulsory unitization, provided that one succeeds in obtaining a fully executed and voluntary unit agreement. Nevertheless for the reasons given in part $B$ of this paper, voluntary agreements also have their dangers, and until the law is further clarified, the alternative methods of unitization present some dilemma of choice.

With regard to compulsory unitization, it is suggested that the position would be improved by the following:

1. The creation of some system of appeal to a court, or perhaps to a special independent tribunal.

2. By providing for the Oil and Gas Conservation Board to be constituted with a membership having no connection with the Department of Mineral Resources and by providing that at all Board hearings the Department of Mineral Rseources have the right to be heard and to give evidence. It is a tribute to the present chairman of the Oil and Gas Conservation Board, the Deputy Minister of Mineral Resources for Saskatchewan, that he has been able to discharge his duties to date with such impartiality, fairness and general satisfaction, but the advantages of such an independent Board would be the following:

(i) The Board would still receive the assistance of information and evidence from the Department, but such information and evidence would be given at the hearing so that all other interested parties would hear it and be able to offer contrary evidence if they disagreed with it.

(ii) The Department would be able to represent the Crown's position as mineral owner in cases where the Crown had a proprietary interest without any embarrassment or difficulty. ${ }^{28}$

2* For other recommended changes in unitization proceedings see Kelly, Unitization in Oil and Gas Industry (1961), 4 Can. Bar J. 80, 96-99. 